\title{
Islamic Acculturation and Local Culture on Nyiramkeun Tradition in Talagawetan Village Majalengka Regency
}

\author{
Ali Syamsuddin \\ Faculty of Social and Political Science, Universitas Majalengka, Indonesia \\ m.ali.syamsudin@gmail.com
}

\begin{abstract}
This research tries to explain the acculturation between Islam and Sundanese culture in the Nyiramkeun tradition. The problems raised in this study are the origin, procession, or implementation of the Nyiramkeun ritual tradition, the form of acculturation between Sundanese and Islamic culture, the meaning or the perceptions of the Talagawetan villagers on the influence of tradition on their lives. This research was field research, according to the theory of acculturation according to Koentjaraningrat. In essence, field research aims to find out the specifics and realities of what happens in society. The anthropological approach used in this research is ethical and emic theory. With data collection techniques used are observation, interviews, and documentation. The research results can be seen from several things, namely, first, the Nyiramkeun ceremony tradition in the village of Talagawetan has existed around the 1820s, namely since the Talaga Manggung government was transferred to Sindangkasih. Second, the acculturation process in the Nyiramkeun ceremony tradition, namely the prayer's recitation. The do'a uses do'a-do'a in Arabic acculturated with the Sundanese language, which is combined in the prayer, where the prayer in the Sundanese language is known as Hadoroh. In addition to the acculturation prayer between Sundanese and Islamic cultures, namely the staging of traditional arts such as karinding, sada awi, debus, gembyung, and jaipong, know that these arts do not originate from Islamic culture but are acculturation between Hindu-Buddhist culture and culture. Islam. The three public perceptions of Islamic acculturation can give the meaning that this Nyiramkeun Traditional Ceremony is an activity to carry out and preserve the heritage of the Talaga Manggung Kingdom, to purify oneself, and as a suggestion to strengthen the ties of brotherhood between descendants of the Talaga Manggung kingdom and members of the community in Talagawetan Village. Generally, as well as maintaining the preservation of the surrounding natural environment. The community has accepted the tradition of the Nyiramkeun ceremony. However, this ceremony tradition was far from Islamic elements, and gradually this tradition has merged with Islamic teachings.
\end{abstract}

Keywords acculturation; culture; tradition; nyiramkeun

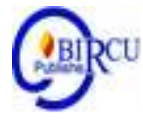

\section{Introduction}

Indonesia has a diversity of cultures and arts. With these various cultures, Indonesia also wants to be known by the international community. With the potential of Indonesian culture, it is expected that it will preserve and develop noble and diverse values as a nation's characteristic asset. Regional cultural diversity is the hallmark of Indonesia's State, and this culture is a supporter of the national cultural wealth. The culture that developed in Indonesia has an important value and a national heritage. According to Clifford Geertz, there are 300 
ethnic groups in Indonesia and use approximately 250 regional languages. This fact causes Indonesia to consist of people with various cultural, ethnic, and religious backgrounds, which are national cultural treasures; in other words, it can be said as a multicultural society.

Along with developing the civilization of thought and the development of an increasingly fast flow of information, the acculturation of cultures between nations was increasingly frequent and easily accepted. It sometimes makes us often forget the culture that exists in our region as regional identity. Civilization and culture are built from noble values by the local community and passed down by the generation. The values and norms are used to maintain the balance of the life order of the citizens. It can be concluded that these values and norms are customs preserved by the community. Indonesia is a very rich and diverse country, both in terms of natural energy sources, language, ethnicity, or culture. Each region's Indonesian customs have their uniqueness according to their geographical location, natural conditions, and the conditions and people thinking method.

The traditional ceremony is one of the traditional community traditions that are still considered to have values relevant to the supportive community's needs. Apart from being a human effort to relate to the ancestors' spirits, it is also a manifestation of the human ability to actively adapt the nature or its environment in a broad sense. The relationship between nature and humans is an irresistible necessity because this relationship has very high sacred values. Traditional ceremonies are closely related to religious rituals or also known as rites. Rites are human religious tools to make changes. It is also said to be symbolic of religion, or that ritual represents "religion and action." (Ghazali, 2011, p. 50)". One of the Sundanese traditional ceremonies is the Nyiramkeun ceremony that the Talagawetan community of Majalengka Regency carries out $h$. Nyiramkeun is an activity to clean artifacts from the Kingdom of Talaga Manggung that their descendants keep with water from the Mayang flowers stored in a large vessel and usually done on Monday, before the 20th, the month of Safar. According to (Cahyaningrat, 2014) Raden Rangga Mantri or Prabu Pucuk Umun conversion to Islam occurred on Monday in Safar, and Sunan Talaga's death Manggung also occurred on Monday in Safar. "Traditional ceremonies are closely related to religious rituals or also known as rites. Rites are human religious tools to make changes. It is also said to be symbolic of religion, or that ritual represents "religion and action"(Ghazali, 2011, p. 50).

Some groups of people in Indonesia still carry out traditional ceremonies and religious rituals based on supernatural powers, death rituals, thanksgiving rituals or slametan, rituals of rejecting disaster, rituals of ruwatan, and others (Marzuki, 2015). These rituals have become a tradition and become part of most people's daily lives because they have been passed down from generation to generation by their ancestors to the next generation. The existence of various rituals and traditions that have been carried out has strengthened the existence of the religion adhered to by the people because various traditions related to the life cycle develop and become stronger when it has traditionally been cultured in the midst of community life, where the essence of its teachings has been included in the traditions of society because it is not just " pepesan kosong " that does not have deep cultural content in society. Associated with Islamic culture as religious principles will often dialogue with the local culture where Islam is located. Although there is one thing that influences both religion and vice versa, local culture is more influential in people's lives. However, both can play a valuable position in making the current culture because there is a dialogue between the rules of religious values that become religious idealism and local cultural values. According to (Ahmad Suriadi, 2019), Islam is a cultural conception divided into large traditions, small traditions, and local traditions; in the process, Islam does not displace culture in society, but Islam has come to enlighten the faith of the people. 
Acculturation is a concept to describe the long process of meeting two or more values belonging to individuals, groups, and communities (Widiana, 2017). Acculturation is a process of adaptation to a culture that is different from the culture owned by the individual in which the individual lives and socializes (Nur'aini, 2021). Ethnicity as one that sustains a sense of primordialism is often interpreted as a social group in a social or cultural system that has a certain meaning or position because of heredity, customs, religion, language, and so on (Angkat, 2019). Whereas culture is defined as culture as a set of assumptions and Beliefs (Kurnaedi, 2020). Research on the acculturation of Islam with local culture was carried out (Roszi \& Mutia, 2018; Widiana, 2017) in his research suggests the acculturation of Islamic values with local culture in influencing people behavior. His research shows that people's behavior is formed by a combination of Islamic values with local culture. It shows that Islamic values greatly affect local culture in society.

Nyiramkeun ceremony is acculturation between local culture and Islam. Nyiramkeun ceremony is a tradition that was born and developed in Talaga District, Majalengka Regency. The Nyiramkeun ceremony is a ritual washing the Talaga Manggung kingdom's heirloom, which was found around the 14th to 17th century. As a cultural heritage, the Nyiramkeun ceremony has been carried out from generation to generation since the Talaga Manggung government was transferred to Sindangkasih around 1820. An ancestral mandate is carried out every year. The Nyiramkeun ceremony has several functions and values; its main function is to respect the Talaga Manggung kingdom's ancestral heritage; besides that, the Nyiramkeun Ceremony functions as a means of friendship between Talaga Manggung descendants and friendship with the surrounding community. The interesting thing about this Nyiramkeun tradition is that the first thing in terms of its activities is washing the Talaga Kingdom's heirlooms. The Nyiramkeun tradition is carried out from generation to generation by the Talaga Manggung foundation, a family descendant of the Talaga Manggung Kingdom. On Monday, the twentieth date of the Month of Safar. The objects washed in this ceremony are a simbarkencana statue, panglurah raden state, a bell, ancient coins, gamelan, kris, machete, sword, cannon, weapon, and pilgrimage clothes (war).

Second, the Nyiramkeun tradition has its uniqueness. The water used to purify the old heirloom comes from 9 springs ( $\mathrm{Ci}$ Nyusu) taken by kuncen using a storage area that comes from yellow bamboo. The nine springs (Ci Nyusu) are: Mount Bitung Springs Situ Sangiang Springs. Wanaperih Springs, Brother's Weak Springs, Ciburuy Springs, Regasari Springs Cikiray Springs, Cicamas Springs, and Nunuk Springs. Third, in terms of acculturation between Islam and local culture, there is a combination of wazifa and watering processions. Water is taken by elders or traditional leaders at the beginning of the month of Safar, Bambu Kuning filled with water is then taken to the Talaga Manggung Museum, to be put into a single jug, then read an Islamic prayer (Cahyaningrat, 2014), that is followed by practicing Islamic teachings in the form of shodaqoh practice aimed at the poor, and finally, the acculturation that appears when the procession of watering heirlooms and it is a combination of religious poetry in the form of sholawat with Sundanese karuhun songs. Based on the description above, it shows that the Nyiramkeun ceremony in Talagawetan Village, Talaga District, Majalengka Regency, presents a unique and interesting ceremony to be discussed more clearly because it displays a form of acculturation between Islam and local culture, this form of acculturation is a form of ancestral cultural heritage as a legacy of the spread of Islam in the archipelago. 


\section{Review of Literatures}

\subsection{Local Culture and Islamic Culture}

In Dutch culture, in English and Arabic, culture is tsaqafah from Latin colored, cultivating, working, fertilizing, and developing, especially cultivating the land or farming. In terms of this meaning, culture's meaning has developed as "all human power and activities to cultivate and change nature." Whereas culture is everything that comes from passion and passion, the higher and purer becomes the top with practical purposes in human relations such as music, poetry, religion, ethics, etc. (Joko Tri Prasetya, 2009, p. 2). Culture is the mind's power in creativity, initiative, taste, and culture creates this initiative and feel. Culture actualized in the form of adat has begun to be understood as a natural phenomenon whose presence in general and inherently contributes to human behavior, such as carrying out religious obligations and social behavior. Some adat forms are indigenous creations, while others may come from outside. Some are ritual, and some are ceremonial. From a religious point of view, there are good customs ('urf sahih) and bad customs (' urf faced); some follow the Shari'a and are stated in the principles of fiqh following the spirit of the moral order according to Islam. Culture plays a very important role in the spread of Islam in the archipelago (Aziz, 2015). Therefore, in a religious celebration, at least three elements are combined: the celebration is considered a custom because it is carried out regularly; it is also religious because all those present uses it to reveal their Muslim identity; and also the glorification of the thought of the ummah in which the internal social ties within the community of adherents are further strengthened. Islam is an order of life that is perfect and complete because Islam itself regulates all kinds of rules ranging from small things to big things, starting from the rules of life in family, school, society, and the environment. We already believe that Islam is the perfect religion but in its perfection and in the implementation of everyday life it still requires interpretations and representations in certain rules. The contact between Islam and local culture does not deny the mutual acculturation or influence one another. Islamic culture is a culture that exists in a society where Islamic practices exist. Islam recognizes the existence of community customs because customs are part of the social life of the community. Islam comes to recognize and accommodate the cultural values and customs considered good and do not conflict with Islamic ideology.

The process of the acculturation form of culture is intertwined when some cultures are closely related to each other in an intensive manner over a long period. After that, each culture will change to familiarize with one another (Alif et al., 2020). Likewise, the research of (Arifin 2016) does not deny that the occurrence of Islamic acculturation is intertwined because of the interaction that has existed for a long time; besides, Islam is a religion that recognizes local racial and cultural variations as God's power and creativity. Islam and culture have an inseparable relationship, in Islam itself there are universal and absolute values throughout the ages. However, Islam as a dogma is not rigid in facing the times and its changes. Islam always presents itself in a flexible form when dealing with the people it meets with various cultures, customs, or traditions. As a historical fact, religion and culture can influence each other because both have values and symbols. Religion is a symbol that symbolizes the value of obedience to God. Culture also contains values and symbols so that humans can live in it. Religion requires a symbol system; in other words, religion requires religious culture. But the two need to be distinguished. Religion is formal, universal, eternal (perennial), and does not know change (absolute). At the same time, culture is particular, relative, and temporary (Andik Wahyu Muqoyyidin, 2013).

In the current era, especially in Java, it is difficult for us to get an original Islamic order. Before Islam entered Indonesia, in Java, Hindu customs and Javanese culture were deeply rooted in the community; as stated by (Arifin 2016), the population's culture and 
religion are influenced by Hindu and Buddhist teachings. Slowly and gradually, without fiercely rejecting the Javanese culture, Islam introduced tolerance and equality. In Javanese Hindu society that emphasizes differences in degrees, Islamic teachings about equality are attractive to Javanese people. Besides, traders who have a cosmopolitan orientation, the call of Islam then became an impetus to take over political power from the hands of the HinduJavanese (Majapahit) rulers (Arifin, 2016); this then greatly influenced the growth of the spread of Islam (Ulum, 2014). Acculturation of Islam with local culture is a form of preservation of local culture (Alif et al., 2020). Islam itself provides many norms or rules about life compared to other religions. When viewed from the relation between Islam and culture, at least two things need to be clarified. As a norm, rule, and all Indonesian society activities, Islam's teachings have become a pattern for society to adopt (Laode Monto Bauto, 2014). The relationship between religion, culture, and society as well as religion functions as a controlling tool and at the same time cultivates it in the sense of expressing what one believes in cultural forms, namely in the form of ethics, building arts, community structures, customs, and others. In religion, the reciprocal influence between religion and culture affects culture, community groups, ethnic groups. Although religion and culture are closely related because they regulate social life and are interrelated, religion and culture must be distinguished. The most significant difference is that religion is a teaching that regulates life related to God and others that comes from God brought by chosen humans. Meanwhile, culture is a social order that is regulated or formed by humans themselves for the sake of the continuity of Together (Fadlia Syechbu, 2017).

\subsection{Research Framework}

All forms of research need a frame of mind in determining the direction of the research. It is to avoid the occurrence of an expansion of meaning as the results in the researcher not focusing on the object. The framework is used to provide concepts in the implementation of research in the field's flow of the researcher's framework. This study will be described as follows. Ritual is related to spiritual beliefs with a specific purpose. Belief in rituals is often considered deviant, especially when it comes to religious matters, but on the other hand, a ritual is a form of cultural preservation. It can be said as a condition because it has been done from generation to generation to generation. There is an opinion that rituals must be carried out, especially in Java areas that still adhere to their culture. People who only know the rituals of the previous generation will believe and follow the existing rituals. However, it is often considered negative if the implementation has been going on for a long time, they will still carry it out. The sacredness of the ritual increases people's trust. This factor sometimes makes people leave the ritual in every event.

\section{Research Methods}

This type of research used to obtain or collect research information data was field research that is directly collected to the data location. At the same time, the researcher is directly involved with the object understudy in the study. This type of research is descriptive more related to a qualitative approach, namely research that is intended to understand phenomena or events regarding the traditions carried out by the research subject to produce or descriptions in the form of oral information from several people who are considered to know better, and the behavior and objects observed. Theoretically, the research is valid data or information about a phenomenon that occurs, namely about the incidence of direct events. Descriptive is a study intended to collect valid data or information about a phenomenon that occurs, namely regarding events that occur directly. 
In determining the data for research based on researchers' ability to reveal an event as objectively as possible and determine informants who are following the terms and conditions so that researchers' data is truly appropriate with the facts. The data sources' determination in this study was based on the researcher's efforts to uncover possible subjective events. The determination of informants as the main source of data exploration is to have the knowledge and deep understanding of the Nyiramkeun ceremony tradition. This research consisted of primary data and secondary data. Primary data was obtained through field research; the author used primary data, namely data or information taken directly by informants, in this case, namely adolescents and several local communities. Secondary data was obtained data that was not taken directly from informants but through documents or books in completing the information needed by researchers. The research instrument consisted of the researcher and used the tools in carrying out research tailored to the desired method. The tools used include interview guides, cellphone cameras, and voice recorders. Methods of data collection in this study were carried out using observation, interviews, field notes, and documentation. The method of processing and analyzing data used the inductive method, namely starting from specific elements and then drawing general conclusions-furthermore, the deductive method, namely analyzing data from general problems than specific conclusions. The data analysis steps were data reduction, data classification, the stage of presenting the data, and checking the data validity.

\section{Discussion}

\subsection{Acculturation Process of Islamic Values to Local Culture at Nyiramkeun Ceremony in Talagawetan Village, Talaga District, Majalengka Regency}

Islamic culture in Indonesia has influenced various aspects of life. However, in its development, the basic pattern of traditional local culture is still strong, so that there is a form of cultural integration called cultural acculturation. Acculturation is a blend of local culture with foreign culture. Local culture is a culture whose development is in the regions and belongs to the ethnic groups of the archipelago. The Indonesian nation is known as a multicultural nation of ethnicity and culture.

Meanwhile, Islamic culture is a creation and work of Muslim humans that depart from the source of Islamic teachings. Islam is spread in society, and there is an interaction between local culture and Islam. The characteristics of Islamic cultural structures such as:

1) Islamic culture is all creations and works produced in the Islamic government or Muslimmajority communities with Islam as a personal religion.

2) Islamic culture is a copyright and a work originating from Islam's basic teachings, regardless of the particular religion or community that originated it even though it is under a non-Muslim government.

The blending of local cultures with Islam greatly affects social life in society. Culture results from human creation and human ideas to improve, heed, and raise citizens' life quality. Culture is a combination of human thoughts, words, and behavior related to the surrounding community or social environment. Culture experiences growth in harmony or goes with the flow to adjust to the environment around it or cultural actors who function actively in it. In Talagawetan Village, Talaga District, Majalengka Regency, there is a mixture of local culture with Islamic culture in the Nyiramkeun ceremony tradition. The Nyiramkeun tradition or ceremony of washing heirlooms in the Talagawetan community has been mixed with Islamic culture in planning, implementation, etc. In the Talagawetan community's life, the old traditions cannot be eliminated even though Islam has entered and developed. The mixing of local culture with Islamic culture (acculturation) in the Talagawetan community does not have many obstacles. In Talagawetan Village's community, 
in the Nyiramkeun ceremony tradition and local cultural practices, there are also Islamic practices that blend into one unified whole. Islamic practice in the tradition of the Nyiramkeun ceremony is seen in choosing the time and day because it uses the date and month of Islam, reading the holy book of the Koran, reading Salawat, and reading prayers in an Islamic way both before and after the Nyiramkeun ceremony is carried out. This study's results reveal empirical facts that Islam's acculturation with culture can foster social interaction in society. It is following the findings of (Adiansyah 2017) In his research, it shows that understanding and deepening the existence of various religious reception processes in culture provides a greater opportunity for the formation between adherents or residents around them, the establishment of a system of cooperation in communities that have a custom.

The research findings showed that the process of acculturation between culture and Islamic teachings carried out in the Nyiramkeun tradition is not contradicting Islamic teachings because implementing this tradition still only nods to the greatness of Allah SWT through reading the Quran verses, prayers, and sholawat. This is in line with the findings made by (Ertanti 2019). The process of acculturation between culture and Islamic teachings as long as it does not conflict with Islamic teachings, but merely seeks divine pleasure in ways that are easily accepted by people who still hold strong traditions in their region. Acculturation between Islam and the Nyiramkeun tradition in Talaga District is included in accommodated acculturation; namely, through this tradition, an attitude of unity between the community is formed, marked by an attitude of cooperation, mutual help, and sharing. This study's results are reinforced by the statement (Roszi \& Mutia, 2018) that Islam's acculturation with local traditions accrued in the archipelago is classified as accommodated acculturation that can adapt to one culture to another. Minimal conflict. It is an adaptation that is a process in which living things adapt to their environmental conditions. This term is also used to describe cultural adaptation.

\subsection{Islamic values contained in the procession of the Nyiramkeun Ceremony in Talagawetan Village, Talaga District, Majalengka Regency}

In the Nyiramkeun ceremony procession, Islamic values are found in every Nyiramkeun ritual procession, always accompanied by Arabic prayers. Like Tawasul (Hadoroh), she recited the welfare prayer, shalawat, Al-Fatihah, and reciting the shahadah. All this is done to avoid idolatry in each human being's hearts, especially the indigenous people of Talagawetan Village. Other Islamic values in this tradition are about the meaning that can be taken, such as the goodness of shodaqoh and friendship. Nyiramkeun Ceremony is always accompanied by the distribution of food sourced from donors; it is then at the end of the activity that there is a distribution of free food to everyone who. Apart from Sodaqoh, other Islamic values found in the Nyiramkeun ceremony are a gathering place because all society elements, from upper to lower classes, even government elements, are also present. In the Nyiramkeun Ceremony process, the cultural heritage of the Talagawetan people has now undergone many very vital changes with the inclusion of Islamic elements Nyiramkeun ceremony.

\subsection{Public Perception of Nyiramkeun Ceremony Tradition in Talagawetan Village, Talaga District, Majalengka Regency}

The presence of the Nyiramkeun ceremony in Talagawetan Village has been the center of public attention from generation to generation, not only in Talaga residents and its surroundings but also to the attention of people who are outside Talaga and even outside Majalengka Regency, such as Kuningan Regency, Ciamis Regency, Cirebon Regency, and Regency Indramayu and others. Based on the research results on several communities taken 
from several community leaders, there is quite a variety of information. Still, some opinions are almost similar to the Nyiramkeun ceremony held once a year; most respondents think that the Nyiramkeun Ceremony is a native local culture from the region. Talagawetan needs to be preserved. The Nyiramkeun ceremony tradition is an ancestral tradition that needs to be preserved and preserved. Still, in practice, it does not leave Islamic teachings so that polytheism does not occur because this ceremony is very sensitive if the community misunderstands it, let alone interpret it. The Nyiramkeun ceremony is just a tradition or custom passed down from the ancestors. Since the reign of Ratu Sunyalarang kingdom, Islam has developed rapidly. This has brought changes to the procession of implementing Nyiramkeun ceremonies, especially in reciting their prayers that follow Islamic teachings .

The nature and cultural essence of the Nyiramkeun traditional ceremony in Talagawetan Village are materialized and structured through the behavior and traditional actions of the Talagawetan Village community, who always maintain and maintain the legacy tradition of the heritage of the Talaga Manggung Kingdom. This Nyiramkeun Traditional Ceremony also has rules that must be obeyed by the Talagawetan Village indigenous people even though they are not binding and do not get any sanctions if anyone breaks them. The Nyiramkeun Traditional Ceremony implementation is also following Sundanese customs and Islamic teachings . The meaning of the Nyiramkeun traditional ceremony lies in the hearts Talagawetan community's heart. However, not all understand the meaning contained in this Nyiramkeun traditional ceremony. Those who know the meaning of the Nyiramkeun Traditional Ceremony are only certain people such as religious leaders, Kuncen, Demang, and community leaders who have long been familiar with the Nyiramkeun Ceremony. The meaning contained in this Nyiramkeun Traditional Ceremony is an activity to carry out and preserve the heritage of the Talaga Manggung Kingdom, to purify oneself, and as a suggestion to strengthen the ties of brotherhood between the descendants of the Talaga Manggung kingdom and members of the community in Talagawetan Village in general, while maintaining the preservation of the natural environment around. There are still some people in Talagawetan Village who have animism.

\section{Conclusion}

Based on the results of research and discussion, it can be concluded that the Nyiramkeun ceremony tradition in the village of Talagawetan has existed around the 1820s since the Talaga Manggung government that is transferred to Sindangkasih. The acculturation process in the Nyiramkeun ceremony procession occurred during the Ratu Sunyalarang and Prabu Pucuk Umu,m, who embraced Islam. Therefore, the Nyiramkeun ceremony that is originally a Buddhist ceremonial tradition, has changed to Islam. The ritual process of the Nyiramkeun ceremony is to purify the objects of the Talaga Manggung kingdom that is said when people believed that royal washing objects could provide prosperity for the people of the kingdom and avoid all the dangers that would befall the Talaga Manggung kingdom. Ceremony Preparation. Before the day of the ceremony, preparations must be held. The main preparation is to form a Nyiramkeun ceremony committee chaired by the head of the Talaga Manggung Foundation. After the committee is formed, then the committee prepares everything from guests, regional art performances, and preparation for taking water from 7 springs that are still related to the Talaga Manggung kingdom to determining the procession of objects from the Talaga kingdom to be shown to the public who participated in the ceremony.

Implementation of the Ceremony. In the implementation of Nyirmakeun, there still preserves the culture of the ancestors. The Talagawetan village community's implementation time is carried out on Monday, the Safar month's twentieth day. Safar month here is taken 
from the calculation of the month in Islamic or in the Islamic calendar. The implementation of the Nyiramkeun ceremony tradition still preserves the previous culture, namely starting with the implementation of the tawasul (hadoroh) activity, which later results from distributing food to the attendees. Then after the hadoroh, in the afternoon, the core activity is carried out, namely, the Nyiramkeun ceremony that is divided into three places, namely in the courtyard of the Talaga Manggung museum as the place for the Nyiramkeun statue of Raden Panglurah with the royal crown of Talaga Manggung, in the Talaga Manggung museum as the place for Nyiramkeun, the statue of Ratu Dewi Simbarkencana and behind the Talaga Manggung museum as the place for Nyiramkeun, tools from the Talaga Manggung kingdom such as kris, spear, kere clothes and so on. The end of the ceremony. The ceremony's final stage is closed by reading the prayer in an Islamic way as a form of gratitude to Allah SWT, and the ceremonial activities can go well. After completion, the Nyiramkeun ceremony ended with various art on the staging yard, both traditional and modern. Besides, in the end, some people want washing water which has the property to fertilize the land and provide an abundance of fortune to the people of Talagawetan Village. Still does not mean that the people of Talagawetan Village worship it, but they respect it, making efforts to conserve resourwater resources. The acculturation that exists in the Nyiramkeun ceremony tradition is the recitation of the prayer. The prayer uses do'a-do'a in Arabic, which is acculturated with the Sundanese language combined in the prayer, where the prayer in Sundanese is known as Hadoroh. In addition to the acculturation prayer between Sundanese and Islamic cultures, namely the staging of traditional arts such as karinding, sada awi, debus, gembyung, and jaipong know that these arts do not originate from Islamic culture but are acculturation between Hindu-Buddhist culture and Islam.

The perception of the Talagawetan people village towards the Nyiramkeun ceremony activities is very diverse. However, they still provide a statement that the Nyiramkeun ceremony needs to be preserved because it is a legacy from the Talaga Manggung kingdom on the land of Talaga. Also, the Nyiramkeun ceremony is a forum for social interaction manifested to strengthen the brotherhood. The public perception of the farmers states that the Nyiramkeun ceremony tradition is very important to be carried out, they believe that the holding of the Nyiramkeun traditional ceremony will help improve the yields of their crops, and also the Nyiramkeun traditional ceremony is one form of their gratitude to Allah SWT who has bestowed Mercy. For civil servants, they think that the implementation of the Nyiramkeun Ceremony tradition teaches the community to help each other ease others' burdens. For private employees and traders, the Nyiramkeun ceremony tradition has a function as a balance to economic disparities and a place to socialize among fellow traders in the village of Talagawetan.

Meanwhile, village officials argue that the Nyiramkeun ceremony tradition is a form of public gratitude and is an ancestral heritage that deserves to be established. From the public perception, it can be interpreted that in Nyiramkeun Traditional Ceremony is an activity to carry out and preserve the heritage of the Talaga Manggung Kingdom to purify oneself, and as a suggestion to strengthen the brotherhood between the descendants of the Talaga Manggung kingdom and members of the community in Talagawetan Village in general. As well as maintaining the preservation of the surrounding natural environment. According to community leaders, the message that "all customs can be adhered to, but little by little" means that the community supports this tradition's existence. However, this ceremony tradition was far from Islamic elements in the past, but gradually this tradition is integrated with Islamic teachings. 


\section{References}

Adiansyah, R. (2017). Persimpangan Antara Agama dan Budaya (Proses Akulturasi Islam dengan Slametan dalam Budaya Jawa). Jurnal Intelektualita: Keislaman, Sosial Dan Sains, 6(2), 295-310. https://doi.org/10.19109/intelektualita.v6i2.1612

Ahmad Suriadi. (2019). Akulturasi Budaya dalam Tradisi Maulid Nabi Muhammad di Nusantara. Khazanah: Jurnal Studi Islam Dan Humaniora, 17(1), 168-191. https://doi.org/10.18592/khazanah.v16i2.2324

Alif, N., Islam, U., Sunan, N., Surabaya, A., Mafthukhatul, L., Islam, U., Sunan, N., Surabaya, A., Ahmala, M., Tinggi, S., Islam, A., Surabaya, T., Jawa, B., \& Islam, B. (2020). Akulturasi Budaya Jawa dan islam. Al'Adalah, 2(2), 143-162.

Andik Wahyu Muqoyyidin. (2013). Dialektika Islam dan Budaya Jawa. Jurnal Kebudayaan Islam, 11(1), 7.

Angkat, M., Katimin, and Nur, A. (2019). Construction of Religious Identity in Pakpak Culture Community in Dairi District. Budapest International Research and Critics Institute-Journal (BIRCI-Journal) Vol 2 (4): 487-494.

Arifin, M. (2016). Islam dan Akulturasi Budaya Lokal di Aceh (Studi terhadap Ritual Rah Uleidi Kuburan dalam Masyarakat Pidie Aceh). Islam Futura, 15(2), 251-284.

Aziz, D. K. (2015). Akulturasi islam dan budaya jawa. Fikrah, I(2), 253-286.

Cahyaningrat. (2014). Tradisi Nyiramkeun Pusaka Kerajaan Talaga Manggung. Cirebontrust.Com.

Ertanti, M. H. S. B. I. R. S. D. W. (2019). Vicratina: Jurnal Pendidikan Islam Volume 4 Nomor 2 Tahun 2019. Vicratina, 4(1), 65-71.

Fadlia Syechbu. (2017). Hubungan Antara Agama dan Ham. In fadliasyechbu.blogspot.co.id. http://fadliasyechbu.blogspot.co.id/2011/04/hubungan-antara-agama-dan-budaya.html

Ghazali, A. (2011). Antropologi Agama. Alfabeta.

Joko Tri Prasetya. (2009). Ilmu Budaya Dasar. Rineka Cipta.

Kurnaedi, E., Agustina, K., and Karyono, O. (2020). Strategy for Improving Service Performance through Organizational Culture and Climate. Budapest International Research and Critics Institute-Journal (BIRCI-Journal) Vol 3 (2): 1360-1368.

Laode Monto Bauto. (2014). Perspektif Agama dan Kebudaan dalam Kehidupan Masyarakat Indonesia : Suatu Tinjauan Sosiologi Agama. Jurnal Pendidikan Ilmu Sosial, 23(2), 24.

Marzuki. (2015). Simbolisme Dalam Upacara Adat: Kajian Terhadap Upacara Adat Mappogau Hanua Pada Masyarakat Adat Karampuang Di Kabupaten Sinjai, Sulawesi Selatan. Universitas Gajah Mada.

Nur'Aini (2021): Effects of Acculturation of Assimilation in the Search for Cultural Identity by the Punjabi Ethnic Minority in Medan, Indonesia, Journal of Human Behavior in the Social Environment, DOI: 10.1080/10911359.2020.1825257

Roszi, jurna petri, \& Mutia. (2018). Akulturasi Nilai-Nilai Budaya Lokal dan Keagamaan dan. Jurnal Kajian Keislaman Dan Kemasyarakatan, 3(2).

Ulum, B. (2014). Islam Jawa: Pertautan Islam Dengan Budaya Lokal. Jurnal Pusaka, Juli$\operatorname{Desem}(2), 28-42$.

Widiana, N. (2017). Budaya Lokal Dalam Tradisi "Nyumpet" Di Desa Sekuro Kecamatan Mlonggo Kabupaten Jepara. Jurnal Ilmu Dakwah, 35(2), 286. https://doi.org/10.21580/jid.v35i2.1611 